\title{
Public Practice of using Hand Sanitizer and Disinfectant in Saudi Arabia
}

\author{
Yousef Ahmed Alomi* iD, BSC. \\ Pharm, MSc. Clin Pharm, BCPS, BCNSP, \\ DiBA, CDE, Critical Care Clinical Pharmacists, \\ TPN Clinical Pharmacist, Freelancer \\ Business Planner, Content Editor and Data \\ Analyst, Riyadh, Saudi Arabia. \\ Basmah Sulimain AlHamdan, \\ Senior Quality Specialist, King Fahad \\ Medical City, Riyadh, SAUDI ARABIA. \\ Sahar Obaid Alosaimi, \\ College of Pharmacy, Taif University, Taif, \\ SAUDI ARABIA. \\ Deema Abdullah Altuwayhir, \\ College of Dentistry, Hail University, Hail, \\ SAUDI ARABIA.

\section{Correspondence:} \\ Dr. Yousef Ahmed Alomi, BSc. Pharm, \\ MSc. Clin Pharm, BCPS, BCNSP, DiBA, CDE, \\ Critical Care Clinical Pharmacists, TPN \\ Clinical Pharmacist, Freelancer Business \\ Planner, Content Editor and Data Analyst, \\ Riyadh 11392, Riyadh, Saudi Arabia.
}

Phone no: +966504417712

E-mail: yalomi@gmail.com
Received: 20-02-2021;

Accepted: 13-04-2021.

Copyright: (c) the author(s),publisher and licensee Pharmacology, Toxicology and Biomedical Reports. This is an open-access article distributed under the terms of the Creative Commons Attribution NonCommercial License, which permits unrestricted non-commercial use, distribution, and reproduction in any medium, provided the original work is properly cited.

This is an open access article distributed under the terms of the Creative Commons AttributionNonCommercial-ShareAlike 4.0 License

\section{Access this article online}

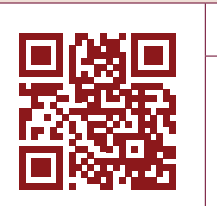

www.ptbreports.org

DOI:

10.5530/PTB.2021.7.16

\begin{abstract}
Objectives: Hand sanitizer and disinfectants have become essential because of the ongoing COVID-19 pandemic. Despite the efficacy of sanitizers and disinfectants in preventing disease transmission, the practice of using them has still not improved among the public. Therefore, in this survey, we analyzed the usages of hand sanitizers and disinfectants in the people of the Kingdom of Saudi Arabia. Designs and Setting: A self-administered, structured questionnaire was sent to the public online, including questions on the responders' demographics and questions about the type of sanitizer or disinfectant used, the situations, places, and locations where the sanitizer was used during the COVID-19 pandemic. Data were collected through the Survey Monkey system and analyzed via SPSS software. Results: A total of 402 individuals responded to the questionnaire. Of them, $32.58 \%$ of the responders were from the western region, and $25.76 \%$ were from the central region, and there were statistically significant differences between all regions $(p=0.000)$. The majority of the responders $(90.88 \%)$ were Saudi nationals. Small- (3.75) and medium-sized (3.13) sanitizers were the most used. In the case of disinfectants, the highest usage of disinfectants was Dettol (3.97) and Clorox (3.13), with statistically significant differences between the responses $(p=0.000)$. The majority of the times when sanitizers or disinfectants were used during COVID-19 was after going out from the market (4.32), before entering the market (4.19), and during entering the house (4.13), with statistically significant differences between responses $(p=0.000)$. Toilet $(214(54.31 \%))$ and a kitchen $(208(53.06 \%))$ were the sites with the majority of the responses, with statistically significant differences between responses $(p<0.001)$. Conclusion: Most people in Saudi Arabia use small sanitizers and phenolic and quaternary ammonium salt-containing disinfectants. There was malpractice of the sanitizer or disinfectant. Therefore, we highly recommend increasing the public's awareness about sanitizer and disinfectants used in Saudi Arabia. Key words: Public, Practice, Usage, Utilization, Sanitizer, Disinfectants, Saudi Arabia.
\end{abstract}

\section{INTRODUCTION}

During the coronavirus period, various healthcare organizations put recommendations for the public for using the sanitizers and disinfectants. ${ }^{1-4}$ They also advised about hand hygiene and the places where sanitizers and disinfectants can be used..$^{1-5}$ There are various types of disinfectants in public practice, ${ }^{1-5}$ such as alcohol, phenol and choline compounds, and quaternary ammonium salts. ${ }^{1-6}$ Each country has local trade products in the market, and it differs from one country to another. Therefore, it is crucial to know if there is malpractice of sanitizer and disinfectants ${ }^{7,8}$ to reduce sanitizerand disinfectant-related problems. ${ }^{1-3,5}$ So far, various studies have been conducted with regard to the practice of infection control during the COVID-19 pandemic.9-12 Furthermore, there are studies on the malpractice of sanitizer and disinfectant use at different places and the adverse effects and poisoning caused due to them. ${ }^{8,13}$ Most of the studies have focused their research on the practice of using sanitizer and disinfectants by healthcare professionals as an infection control measure and did not discuss the sanitizer and disinfectants. ${ }^{11,14,15}$ However, only a few studies have addressed the practice of sanitizer and disinfectants used by the public. ${ }^{16,17}$ Therefore, in this study, we aimed to analyze the general rule of sanitizer and disinfectant used during the ongoing COVID-19 pandemic in the Kingdom of Saudi Arabia.

\section{MATERIALS AND METHODS}

This quantitative cross-sectional survey study was conducted in Saudi Arabia. In this study, we distributed a self-administered electronic survey for four months. The study included all Saudi nationals, and any incomplete responses or responses from outside Saudi Arabia were excluded. An online self-developed questionnaire was distributed to members of the public across all regions in Saudi Arabia. The survey mainly focused on collecting demographic data, including location, gender, marital status, age, qualification, occupational status, and monthly income. In contrast, the second part of the questionnaire included questions on the type, situations, places, or location of hand sanitizers or disinfectants during the COVID-19 pandemic. We used 5-point Likert response scale system to obtain responses. The survey was distributed to a convenient sample of public responders. It was spread through social media such as WhatsApp, Telegram, and via faceto-face contact. A reminder message was sent once every 1-2 weeks. The completed surveys obtained from Saudi nationals were included in the final analysis. According to the previous 
literature, the sample size was calculated with unlimited population size, a population percentage of $50 \%$, a confidence level of $95 \%$, a z score of 1.96 , a margin of error of $5 \%$, and a drop-out rate of $5 \%$. Consequently, the sample size was calculated to be 399 with the power of study of $80 \% .{ }^{18-20}$ The response rate required for the estimated sample size was at least $60-70 \%{ }^{20,21}$ Expert reviewers and pilot testing validated the survey data. We performed reliability tests such as McDonald's $\omega$, Cronbach's $\alpha$, Guttman's $\lambda 2$, and Guttman's $\lambda 6$. The data were collected through the Survey Monkey system and analyzed with Statistical Package of Social Sciences (SPSS), Jeffery's Amazing Statistics Program (JASP), and Microsoft Excel software (version 16). We performed descriptive and frequency analysis, the goodness of fit analysis, correlation analysis, and inferential analysis between independent variable responders. The STROBE (Strengthening the reporting of observational studies in epidemiology statement: guidelines for reporting observational studies) guided the reporting of this study. ${ }^{22-24}$

\section{RESULTS}

A total of 402 individuals responded to the questionnaire. Only participants who completed all the sections in the questionnaire were included. The reliability of the questionnaire was tested through McDonald's $\omega$ was 0.949 , Cronbach's $\alpha$ was 0.948 , Guttman's $\lambda 2$ was 0.951 , Guttman's $\lambda 6$ was 0.971 , and Greatest Lower Bound was 0.984 . Table 1 shows the socio-demographic characteristics of the responders and the analysis of the questionnaire. Of the total responders, $32.58 \%$ were from the western region, and $25.76 \%$ were from the central region, with statistically significant differences between other regions $(p<0.001)$. The majority of the responders $(90.88 \%)$ were Saudi nationals. In addition, $65.17 \%$ of the responders were females, with statistically significant differences between males and females $(p<0.001)$. Based on the age of the responders, we categorized the responders into five sub-categories. The most prevalent age group was between 18 and 29 years, with $50.25 \%$ of the responses obtained from this age group, and the differences were statistically significant between all age groups $(p<0.001)$. About the education level, $65.67 \%$ of the responders had obtained a bachelor's degree, $34.91 \%$ were employed, $34.16 \%$ were still students, and only $26.18 \%$ were non-employees, with statistically significant differences among all occupational jobs $(p<0.001)$. Participants were also asked if they were working in the medical field. Only $36.82 \%$ of the responders were healthcare practitioners; of them, $78.38 \%$ were pharmacists, with statistically significant differences between specialties $(p<0.001)$ (Table 1) (Table 2).

Next, the responders were asked to choose a level of practice for the usage of sanitizer or disinfectant types during the COVID-19 pandemic. According to the results, most of the responders used small-sized hand sanitizer (3.75) and medium-sized hand sanitizer (3.13). On the contrary, the frequently used disinfectant was Dettol (3.97), Clorox (3.13), and The Giant (2.89). In contrast, the least used disinfectant was Panda Bleach (1.66), Anibac (1.67), and Shear (1.67), with statistically significant differences between responses $(p<0.001)$ (Table 3$)$ (Table 3$)$. Besides, the responders were asked to choose the situation for sanitizer or disinfectant during COVID-19. According to the results, the most frequently answered situation was after leaving the market (4.32), before entering the market (4.19), and before joining their house (4.13). On the contrary, the least frequently answered situation was after house garden care (3.12), after handling of animals or birds (3.27), and before climbing the stairs (3.37), with statistically significant differences between responses $(p<0.001)$ (Table 4$)$. In addition, the responders were asked to choose a level of practice in various places or locations during COVID-19. According to the results, the most frequently responded site or location was a toilet (214 (54.31\%)), kitchen (208 (53.06\%)), and washing sink (209 $(53.05 \%))$. On the contrary, the less frequently responded site or

\begin{tabular}{|c|c|c|c|}
\hline Nationality & Response Count & Response Percent & $p$-value \\
\hline Central area & 102 & $25.76 \%$ & \multirow[t]{5}{*}{0.000} \\
\hline North area & 54 & $13.64 \%$ & \\
\hline South area & 76 & $19.19 \%$ & \\
\hline East area & 35 & $8.84 \%$ & \\
\hline West area & 129 & $32.58 \%$ & \\
\hline Answered question & 396 & & \\
\hline Skipped question & 6 & & \\
\hline Nationality & Response Count & Response Percent & \\
\hline Saudi & 339 & $90.88 \%$ & \multirow[t]{2}{*}{0.000} \\
\hline Non-Saudi & 34 & $9.12 \%$ & \\
\hline Answered question & 373 & & \\
\hline Skipped question & 29 & & \\
\hline Gender & Response Count & Response Percent & \\
\hline Male & 140 & $80.45 \%$ & \multirow[t]{2}{*}{0.000} \\
\hline Female & 262 & $19.55 \%$ & \\
\hline Answered question & 402 & & \\
\hline Skipped question & 0 & & \\
\hline Age & Response Count & Response Percent & \\
\hline$<18$ & 35 & $8.71 \%$ & \multirow[t]{5}{*}{0.000} \\
\hline $18-29$ & 202 & $50.25 \%$ & \\
\hline $30-44$ & 110 & $27.36 \%$ & \\
\hline $45-60$ & 41 & $10.20 \%$ & \\
\hline$>60$ & 14 & $3.48 \%$ & \\
\hline Answered question & 402 & & \\
\hline Skipped question & 0 & & \\
\hline
\end{tabular}

Table 2: Social and professional information of responders.

\begin{tabular}{|c|c|c|c|}
\hline Responder Qualifications & $\begin{array}{l}\text { Response } \\
\text { Count }\end{array}$ & $\begin{array}{l}\text { Response } \\
\text { Percent }\end{array}$ & $p$-value \\
\hline Doctorate & 8 & $1.99 \%$ & \multirow[t]{8}{*}{0.000} \\
\hline Master's degree & 37 & $9.20 \%$ & \\
\hline Bachelor's degree & 264 & $65.67 \%$ & \\
\hline Diploma & 32 & $7.96 \%$ & \\
\hline High school & 48 & $11.94 \%$ & \\
\hline Intermediate School & 10 & $2.49 \%$ & \\
\hline Primary School & 2 & $0.50 \%$ & \\
\hline Not educated & 1 & $0.25 \%$ & \\
\hline Answered question & 402 & & \\
\hline Skipped question & 0 & & \\
\hline Occupational status & $\begin{array}{c}\text { Response } \\
\text { Count }\end{array}$ & $\begin{array}{l}\text { Response } \\
\text { Percent }\end{array}$ & \\
\hline Employee & 140 & $34.91 \%$ & \multirow[t]{4}{*}{0.000} \\
\hline Non-employee & 105 & $26.18 \%$ & \\
\hline Student & 137 & $34.16 \%$ & \\
\hline Retried & 19 & $4.74 \%$ & \\
\hline Answered question & 401 & & \\
\hline Skipped question & 1 & & \\
\hline $\begin{array}{l}\text { Are you a health care practitioner } \\
\text { (Medical Doctor- Dentist- } \\
\text { Pharmacist- Nurse- Others? }\end{array}$ & $\begin{array}{c}\text { Response } \\
\text { Count }\end{array}$ & $\begin{array}{c}\text { Response } \\
\text { Percent }\end{array}$ & \\
\hline Yes & 148 & $36.82 \%$ & \multirow[t]{2}{*}{0.000} \\
\hline No & 254 & $63.18 \%$ & \\
\hline Answered question & 402 & & \\
\hline Skipped question & $\mathbf{0}$ & & \\
\hline $\begin{array}{l}\text { If you are a health care } \\
\text { practitioner, you are a }\end{array}$ & $\begin{array}{c}\text { Response } \\
\text { Count }\end{array}$ & $\begin{array}{c}\text { Response } \\
\text { Percent }\end{array}$ & \\
\hline Physician & 11 & $7.43 \%$ & \multirow[t]{4}{*}{0.000} \\
\hline Dentist & 9 & $6.08 \%$ & \\
\hline Pharmacist & 116 & $78.38 \%$ & \\
\hline Nurse & 4 & $2.70 \%$ & \\
\hline Other (please specify) & 8 & $5.41 \%$ & \\
\hline Answered question & 148 & & \\
\hline Skipped question & 254 & & \\
\hline
\end{tabular}


Alomi YA et.al. Public Practice of using Sanitizer and Disinfectant in Saudi Arabia

Table 3: Frequency usage of hand sanitizer or disinfectant types during COVID-19.

\begin{tabular}{|c|c|c|c|c|c|c|c|c|c|c|c|c|c|}
\hline & \multicolumn{2}{|c|}{ always } & \multicolumn{2}{|c|}{ most of the time } & \multicolumn{2}{|c|}{ sometimes } & \multicolumn{2}{|c|}{ rarely } & \multicolumn{2}{|c|}{ Never } & \multirow{2}{*}{$\begin{array}{c}\text { Total } \\
391 \\
\end{array}$} & \multirow[b]{2}{*}{3.75} & \multirow{2}{*}{$\begin{array}{c}\boldsymbol{p} \text {-value } \\
0.000\end{array}$} \\
\hline Small size sanitizer & $31.20 \%$ & 122 & $29.67 \%$ & 116 & $27.11 \%$ & 106 & $7.42 \%$ & 29 & $4.60 \%$ & 18 & & & \\
\hline Medium size sanitizer & $12.21 \%$ & 47 & $22.60 \%$ & 87 & $41.56 \%$ & 160 & $13.51 \%$ & 52 & $10.13 \%$ & 39 & 385 & 3.13 & 0.000 \\
\hline Large size sanitizer & $13.35 \%$ & 51 & $15.18 \%$ & 58 & $29.06 \%$ & 111 & $24.87 \%$ & 95 & $17.54 \%$ & 67 & 382 & 2.82 & 0.000 \\
\hline Wwall sanitizer & $12.24 \%$ & 47 & $13.28 \%$ & 51 & $22.40 \%$ & 86 & $23.96 \%$ & 92 & $28.13 \%$ & 108 & 384 & 2.58 & 0.000 \\
\hline Chlorax & $22.22 \%$ & 86 & $19.90 \%$ & 77 & $25.84 \%$ & 100 & $13.18 \%$ & 51 & $18.86 \%$ & 73 & 387 & 3.13 & 0.002 \\
\hline Rex & $4.46 \%$ & 17 & $6.82 \%$ & 26 & $11.55 \%$ & 44 & $14.96 \%$ & 57 & $62.20 \%$ & 237 & 381 & 1.76 & 0.000 \\
\hline Shear & $3.96 \%$ & 15 & $4.75 \%$ & 18 & $11.61 \%$ & 44 & $13.98 \%$ & 53 & $65.70 \%$ & 249 & 379 & 1.67 & 0.000 \\
\hline $\mathrm{Dac}$ & $15.03 \%$ & 58 & $15.03 \%$ & 58 & $25.91 \%$ & 100 & $12.44 \%$ & 48 & $31.61 \%$ & 122 & 386 & 2.69 & 0.000 \\
\hline Gento & $7.87 \%$ & 30 & $13.91 \%$ & 53 & $24.67 \%$ & 94 & $12.07 \%$ & 46 & $41.47 \%$ & 158 & 381 & 2.35 & 0.000 \\
\hline Sunova & $5.03 \%$ & 19 & $6.35 \%$ & 24 & $18.25 \%$ & 69 & $12.96 \%$ & 49 & $57.41 \%$ & 217 & 378 & 1.89 & 0.000 \\
\hline Jif & $9.14 \%$ & 35 & $16.71 \%$ & 64 & $23.50 \%$ & 90 & $16.19 \%$ & 62 & $34.46 \%$ & 132 & 383 & 2.50 & 0.000 \\
\hline Hapric & $4.76 \%$ & 18 & $9.79 \%$ & 37 & $15.61 \%$ & 59 & $15.34 \%$ & 58 & $54.50 \%$ & 206 & 378 & 1.95 & 0.000 \\
\hline Dettol & $39.29 \%$ & 154 & $20.92 \%$ & 82 & $25.77 \%$ & 101 & $7.14 \%$ & 28 & $6.89 \%$ & 27 & 392 & 3.79 & 0.000 \\
\hline Flash & $7.01 \%$ & 27 & $10.13 \%$ & 39 & $25.97 \%$ & 100 & $18.70 \%$ & 72 & $38.18 \%$ & 147 & 385 & 2.29 & 0.000 \\
\hline Smac & $4.20 \%$ & 16 & $6.30 \%$ & 24 & $15.22 \%$ & 58 & $14.17 \%$ & 54 & $60.10 \%$ & 229 & 381 & 1.80 & 0.000 \\
\hline Drummer & $2.13 \%$ & 8 & $6.67 \%$ & 25 & $15.47 \%$ & 58 & $14.40 \%$ & 54 & $61.33 \%$ & 230 & 375 & 1.74 & 0.000 \\
\hline Udo & $2.09 \%$ & 8 & $4.45 \%$ & 17 & $14.92 \%$ & 57 & $15.97 \%$ & 61 & $62.57 \%$ & 239 & 382 & 1.68 & 0.000 \\
\hline Panda Bleach & $2.62 \%$ & 10 & $5.25 \%$ & 20 & $13.65 \%$ & 52 & $12.07 \%$ & 46 & $66.40 \%$ & 253 & 381 & 1.66 & 0.000 \\
\hline Vanish & $10.03 \%$ & 38 & $11.35 \%$ & 43 & $23.48 \%$ & 89 & $15.57 \%$ & 59 & $39.58 \%$ & 150 & 379 & 2.37 & 0.000 \\
\hline The Giant & $20.89 \%$ & 80 & $14.10 \%$ & 54 & $25.85 \%$ & 99 & $10.97 \%$ & 42 & $28.20 \%$ & 108 & 383 & 2.89 & 0.000 \\
\hline Anibac & $3.16 \%$ & 12 & $7.37 \%$ & 28 & $10.26 \%$ & 39 & $12.11 \%$ & 46 & $67.11 \%$ & 255 & 380 & 1.67 & 0.000 \\
\hline Answered & & & & & & & & & & & 402 & & \\
\hline Skipped & & & & & & & & & & & 0 & & \\
\hline
\end{tabular}

Table 4: Frequency of usage the situations hand sanitizer or disinfectant during Covid-19.

\begin{tabular}{|c|c|c|c|c|c|c|c|c|c|c|c|c|c|}
\hline \multirow[b]{2}{*}{ Entering house } & \multicolumn{2}{|c|}{ always } & \multicolumn{2}{|c|}{ most of the time } & \multicolumn{2}{|c|}{ sometimes } & \multicolumn{2}{|c|}{ rarely } & \multicolumn{2}{|c|}{ Never } & \multirow{2}{*}{$\begin{array}{c}\text { Total } \\
395 \\
\end{array}$} & \multirow[b]{2}{*}{4.13} & \multirow{2}{*}{$\frac{p \text {-value }}{0.000}$} \\
\hline & $53.42 \%$ & 211 & $19.49 \%$ & 77 & $15.95 \%$ & 63 & $9.11 \%$ & 36 & $2.03 \%$ & 8 & & & \\
\hline Getting out from house & $41.48 \%$ & 163 & $19.08 \%$ & 75 & $22.90 \%$ & 90 & $10.69 \%$ & 42 & $5.85 \%$ & 23 & 393 & 3.80 & 0.000 \\
\hline After driving the car & $37.08 \%$ & 145 & $28.64 \%$ & 112 & $19.18 \%$ & 75 & $9.97 \%$ & 39 & $5.12 \%$ & 20 & 391 & 3.83 & 0.000 \\
\hline After going out from toilet & $55.36 \%$ & 217 & $14.29 \%$ & 56 & $15.31 \%$ & 60 & $10.71 \%$ & 42 & $4.34 \%$ & 17 & 392 & 4.06 & 0.000 \\
\hline Entering elevator & $41.73 \%$ & 164 & $18.32 \%$ & 72 & $21.37 \%$ & 84 & $13.74 \%$ & 54 & $4.83 \%$ & 19 & 393 & 3.78 & 0.000 \\
\hline Before climbing the stairs & $30.79 \%$ & 121 & $15.27 \%$ & 60 & $24.43 \%$ & 96 & $19.59 \%$ & 77 & $9.92 \%$ & 39 & 393 & 3.37 & 0.000 \\
\hline After climbing the stairs & $41.07 \%$ & 161 & $16.07 \%$ & 63 & $19.39 \%$ & 76 & $16.07 \%$ & 63 & $7.40 \%$ & 29 & 392 & 3.67 & 0.000 \\
\hline Before work footprint & $40.57 \%$ & 157 & $16.54 \%$ & 64 & $15.25 \%$ & 59 & $13.44 \%$ & 52 & $14.21 \%$ & 55 & 387 & 3.56 & 0.000 \\
\hline After work footprint & $55.06 \%$ & 212 & $14.55 \%$ & 56 & $13.77 \%$ & 53 & $6.49 \%$ & 25 & $10.13 \%$ & 39 & 385 & 3.98 & 0.000 \\
\hline After sneezing & $41.33 \%$ & 162 & $15.56 \%$ & 61 & $21.17 \%$ & 83 & $12.76 \%$ & 50 & $9.18 \%$ & 36 & 392 & 3.67 & 0.000 \\
\hline After toughing soft surfaces & $52.42 \%$ & 206 & $21.12 \%$ & 83 & $13.74 \%$ & 54 & $8.91 \%$ & 35 & $3.82 \%$ & 15 & 393 & 4.09 & 0.000 \\
\hline Before entering the market & $56.49 \%$ & 222 & $19.85 \%$ & 78 & $13.49 \%$ & 53 & $6.11 \%$ & 24 & $4.07 \%$ & 16 & 393 & 4.19 & 0.000 \\
\hline After going out from market & $62.24 \%$ & 244 & $17.60 \%$ & 69 & $12.24 \%$ & 48 & $5.87 \%$ & 23 & $2.04 \%$ & 8 & 392 & 4.32 & 0.000 \\
\hline After house garden care & $26.92 \%$ & 105 & $14.62 \%$ & 57 & $20.51 \%$ & 80 & $19.74 \%$ & 77 & $18.21 \%$ & 71 & 390 & 3.12 & 0.000 \\
\hline After gloves removal & $42.05 \%$ & 164 & $20.51 \%$ & 80 & $19.74 \%$ & 77 & $9.49 \%$ & 37 & $8.21 \%$ & 32 & 390 & 3.79 & 0.000 \\
\hline After handling of animal or birds & $33.33 \%$ & 128 & $14.58 \%$ & 56 & $19.79 \%$ & 76 & $10.16 \%$ & 39 & $22.14 \%$ & 85 & 384 & 3.27 & 0.000 \\
\hline After caring of sick patients & $57.95 \%$ & 226 & $14.10 \%$ & 55 & $11.79 \%$ & 46 & $6.92 \%$ & 27 & $9.23 \%$ & 36 & 390 & 4.05 & 0.000 \\
\hline Answered & & & & & & & & & & Answered & 396 & & \\
\hline Skipped & & & & & & & & & & Skipped & 6 & & \\
\hline
\end{tabular}


Table 5: Frequency of the places or locations usage of disinfectant.

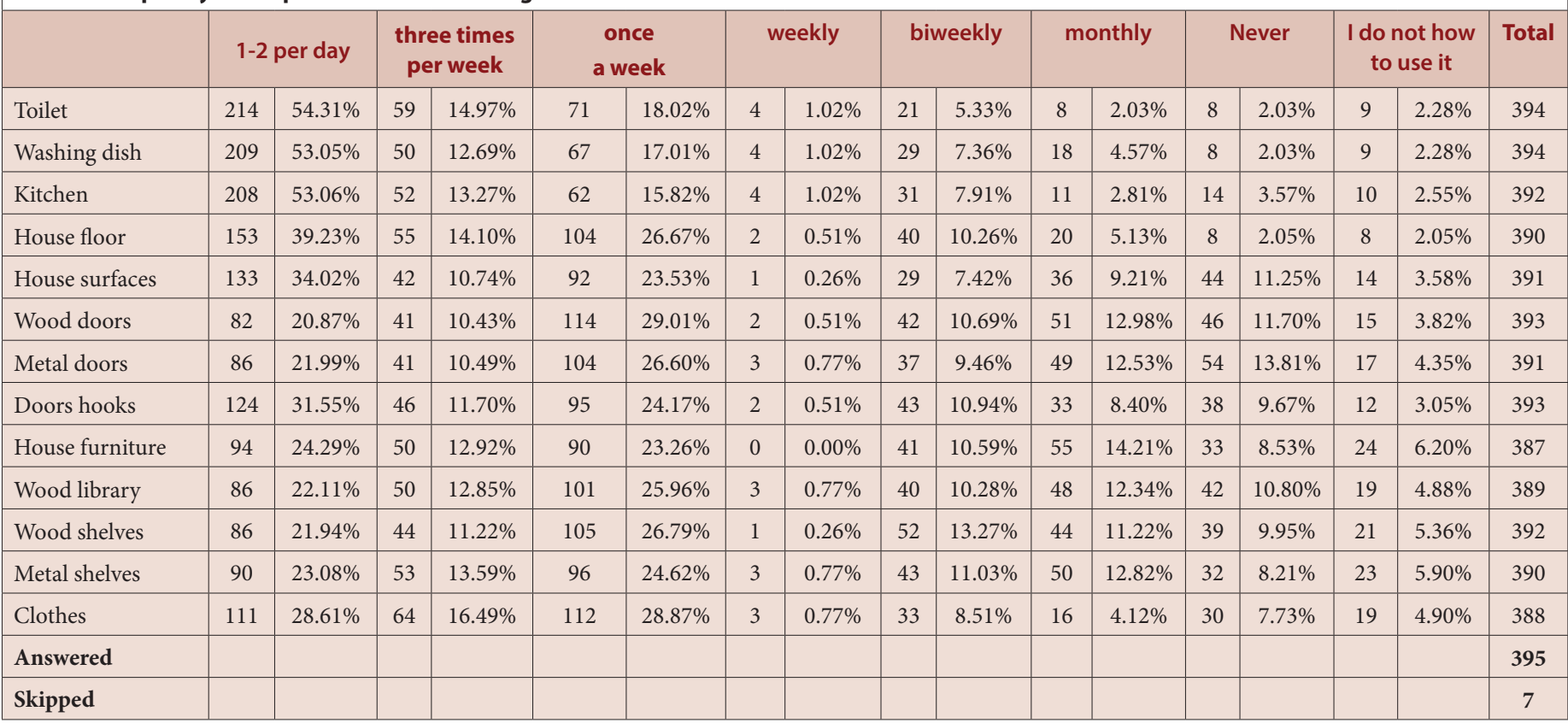

location was wood doors (82 $(20.87 \%))$, wood shelves (86 $(21.94 \%))$, and metal doors (86 (21.99\%)), with statistically significant differences among responders $(p<0.001)$ (Table 5$)$.

\section{Factors affecting the frequency of usage of hand sanitizer or disinfectant types and the situations during COVID-19}

Several factors affected the frequency of usage of hand sanitizers and disinfectants during COVID-19. Using independent samples KruskalWallis test and the Bonferroni correction for multiple tests, we adjusted the significant values. The factors that affected the frequency of hand sanitizer usage and disinfectant types during COVID-19 were locations, nationality, gender, age, qualification, occupational status, and whether the responder was a healthcare practitioner (e.g., doctor, dentist, pharmacist, and nurse). Most of the factors did not affect the practice of frequency of usage of sanitizers and disinfectants, with a non-statistically significant difference $(p>0.05)$. Five locations affected the frequency of use of hand sanitizer and disinfectants. The western region showed the highest scores (3.6527), followed by the northern region with the lowest score (3.2445), and there was a statistically significant difference between the regions ( $p=0.024)$. Eight levels of education affected the frequency of usage of hand sanitizer and disinfectants. The lowest (3.0813) score was obtained for those who completed their high school, with a statistically significant difference between all levels of education $(p=0.000)$. Five different age groups affected the frequency of usage of hand sanitizers and disinfectants. The lowest score (2.8424) was obtained for the age group of $<18$ years, with a statistically significant difference between all age groups $(p=0.000)$. Healthcare professionals most frequently used hand sanitizers (3.6084) than non-healthcare professionals (2.5033), with a statistically significant difference between them $(p=0.028)$.

The relationship between the frequency of usage of hand sanitizer and disinfectant types during the COVID-19 pandemic was analyzed. Multiple regression analysis was performed with the frequency of hand sanitizer or disinfectant types as the dependent variable and factors affecting it as an expletory variable. The analysis revealed a medium relationship
( $\mathrm{R}=0.253$ with $\mathrm{p}=0.001$ ) between the frequency of hand sanitizer usage and disinfectant types and factors affecting it. Five out of seven factors revealed non-significant differences $(p>0.05)$. However, age explained $12.7 \%$ of the positive relationship, and educational level explained $18.8 \%$ of the negative relationship between them, with a statistically significant ( $p=0.019$ and 0.001 , respectively) difference between them. This result was confirmed by Bootstrap analysis. Furthermore, the relationship was verified by the non-existence of multi-collinearity with the current position factor with Variance Inflation Factor (VIF) of 1.108 and 1.208, which was less than 3 or $5^{25-27}$ (Table 6).

Various factors affected the frequency of hand sanitizers and disinfectants usage in different situations during the COVID-19 pandemic. However, some of the factors (e.g., nationality, educational level, and worksite) did not affect the usage of hand sanitizers and disinfectants in various situations, with a non-statistically significant difference between them $(p>0.05)$. Five locations involved hand sanitizer and disinfectant usage in various situations, with a statistically significant difference $(p=0.019)$. However, there are no differences among regions with non-statistically significant differences $(p>0.05)$. Gender affected the usage based on situations. Females showed lower scores (2.0820) than males (2.4538), with a statistically significant difference between them $(p=0.000)$. Five different age groups affected the situation in which sanitizers and disinfectants were used, with the highest score (2.580) for the responders in the age group of $<18$ years. Followed by those in the age group of $18-29$ years (2.1005) and $30-40$ years (2.1694), with a statistically significant difference between all age groups $(p=0.001)$. The score for the responders with non-healthcare profession had the highest score (2.3406) than those in the healthcare profession (1.9879), with a statistically significant difference between them $(p=0.000)$.

The relationship between the frequency of hand sanitizer usage or disinfectants at different situations during the ongoing COVID-19 pandemic was studied. Multiple regression analysis was performed with a frequency of usage as the dependent variable and factors affecting it as an expletory variable. The analysis revealed a weak relationship $(\mathrm{R}=0.301$ with $p=0.001$ ) between the frequency of use in different situations and 
Table 6: Multiple regression of Factors with Frequency types of hand sanitizer or disinfectant usage during Covid-19. ${ }^{\mathrm{a}}$

\begin{tabular}{|c|c|c|c|c|c|c|c|c|c|c|c|c|c|c|}
\hline \multirow{2}{*}{\multicolumn{2}{|c|}{ Model }} & \multirow[b]{2}{*}{$\mathbf{R}$} & \multirow[b]{2}{*}{$\begin{array}{c}\mathbf{R} \\
\text { Square }\end{array}$} & \multirow[b]{2}{*}{$F$} & \multirow[b]{2}{*}{ Sig. } & \multicolumn{2}{|c|}{$\begin{array}{l}\text { Unstandardized } \\
\text { Coefficients }\end{array}$} & \multirow{2}{*}{$\begin{array}{c}\begin{array}{c}\text { Standardized } \\
\text { Coefficients }\end{array} \\
\text { Beta }\end{array}$} & \multirow[b]{2}{*}{$t$} & \multirow[b]{2}{*}{ Sig. } & \multicolumn{2}{|c|}{$\begin{array}{l}95.0 \% \text { Confidence } \\
\text { Interval for B }\end{array}$} & \multicolumn{2}{|c|}{$\begin{array}{l}\text { Collinearity } \\
\text { Statistics }\end{array}$} \\
\hline & & & & & & B & $\begin{array}{l}\text { Std. } \\
\text { Error }\end{array}$ & & & & $\begin{array}{l}\text { Lower } \\
\text { Bound }\end{array}$ & $\begin{array}{l}\text { Upper } \\
\text { Bound }\end{array}$ & Tolerance & VIF \\
\hline \multirow[t]{7}{*}{1} & (Constant) & \multirow[t]{7}{*}{$.253^{\mathrm{b}}$} & \multirow[t]{7}{*}{.064} & \multirow[t]{7}{*}{3.490} & \multirow[t]{7}{*}{$.001^{\mathrm{b}}$} & 3.721 & 0.335 & & 11.108 & 0.000 & 3.062 & 4.380 & & \\
\hline & Locations & & & & & 0.036 & 0.027 & 0.072 & 1.330 & 0.184 & -0.017 & 0.089 & 0.901 & 1.110 \\
\hline & Sector of work & & & & & 0.068 & 0.048 & 0.079 & 1.400 & 0.162 & -0.027 & 0.162 & 0.825 & 1.212 \\
\hline & Nationality & & & & & 0.028 & 0.144 & 0.010 & 0.197 & 0.844 & -0.255 & 0.311 & 0.971 & 1.030 \\
\hline & Gender & & & & & -0.084 & 0.093 & -0.050 & -0.903 & 0.367 & -0.267 & 0.099 & 0.850 & 1.177 \\
\hline & Educational level & & & & & -0.155 & 0.046 & -0.188 & -3.341 & 0.001 & -0.246 & -0.064 & 0.828 & 1.208 \\
\hline & $\begin{array}{l}\text { Are you from } \\
\text { a health care } \\
\text { professional }\end{array}$ & & & & & -0.055 & 0.090 & -0.033 & -0.612 & 0.541 & -0.233 & 0.122 & 0.889 & 1.124 \\
\hline
\end{tabular}

a. Dependent Variable: the Frequency types of hand sanitizer or disinfectant usage during convid-19a ${ }^{\text {a }}$ Predictors: (Constant), Location, Site of work, Age, Nationality, Gender, Educational level, Are you from the health care professional (Medical Doctor- Dentist- Pharmacist- Nurse- Others),

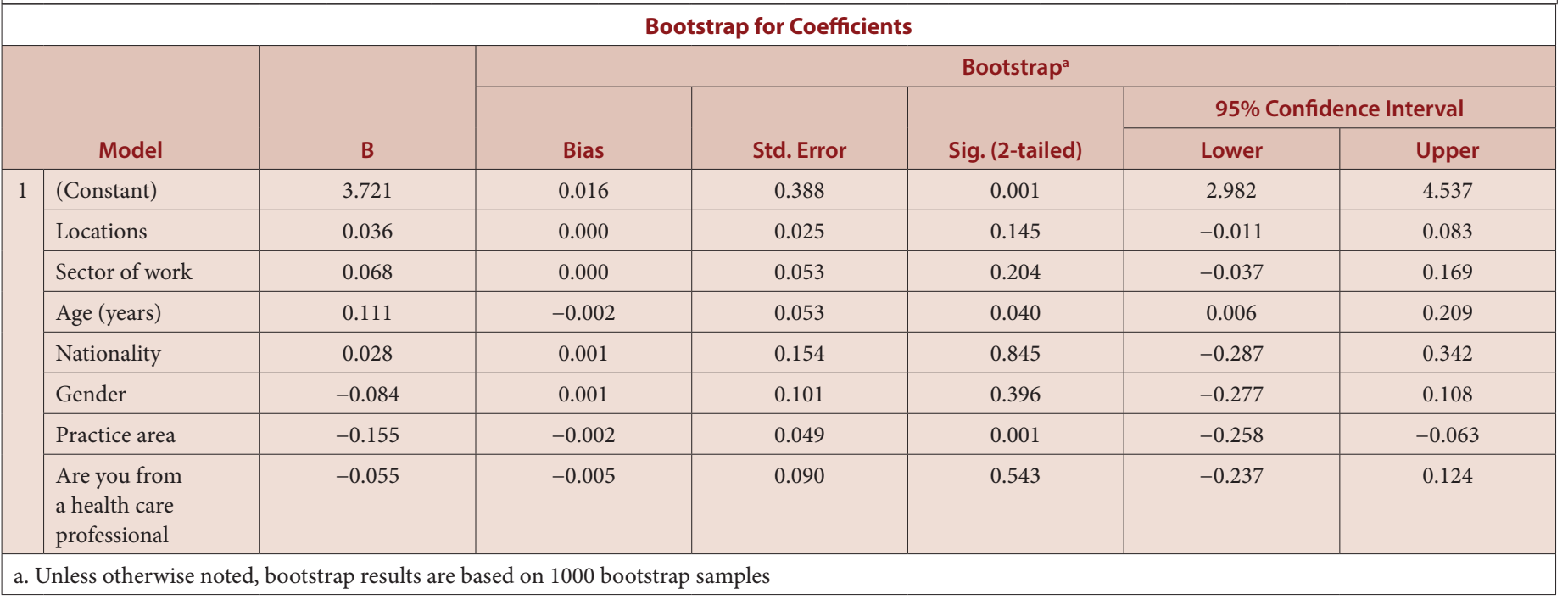

its factors. Five out of seven factors showed non-significant differences ( $p>0.05)$. However, gender explained $23 \%$ of the negative relationship, and the responders from the healthcare profession explained $19.4 \%$ of the positive relationship, with a statistically significant $(p=0.000$ and 0.000 , respectively) difference. The bootstrap model confirmed this result. Furthermore, the non-existence of multi-collinearity verified the relationship with the current position factor with VIF of 1.177 and 1.122, respectively, which is less than 3 or $5^{25-27}$ (Table 7).

\section{DISCUSSION}

During COVID 19, various recommendations were passed for the public to follow, especially on the use of sanitizers and disinfectants in order to prevent the transmission of COVID-19.$^{1-4}$ However, sanitizers and disinfectants can be misused by the public. ${ }^{7,8}$ That can lead to an unnecessary economic burden on the healthcare system. ${ }^{1-4}$ The people do not widely know the exact method of use of sanitizers and disinfectants in Saudi Arabia. Therefore, in this study, we aimed to assess the use of sanitizer and disinfectants by the local people during the COVID-19 period. We used a self-administered validated high-reliability electronic survey and distributed it to the public locally. There were responders from different regions, gender, nationality, age, occupational status, and responders from healthcare professionals, which was not similar to previous studies. ${ }^{16,17}$ The findings showed that most of the people in Saudi Arabia used small-sized hand sanitizer. The most commonly used disinfectant types were Dettol (phenol products) and Clorox (quaternary ammonium salts), which can be used in the toilet and kitchen and on hard surfaces. Responders preferred to use disinfectants with brand names than generic ones. Most of the responders used the sanitizer and disinfectant after out or in the general market or before entering the house, which is expected because the responders encountered various people when they were in the market. They used it before entering the house to prevent transmission of the virus to the family members. In contrast, the responders did not use much during cleaning their house garden, caring for their animals, or while climbing stairs. Sanitizers and disinfectants were used the most in the toilet and kitchen or after washing in the sink, similar to a previous study finding. ${ }^{17}$ On the contrary, wooden doors and shelves were never applied with sanitizer or disinfectant because they were less likely to transmit the virus.

\section{Factors affecting the type of hand sanitizer and} disinfectant used and the situation in which they were used during COVID-19

Various factors affected the use of different types of hand sanitizers and disinfectants during the ongoing COVID-19. According to the results, 


\begin{tabular}{|c|c|c|c|c|c|c|c|c|c|c|c|c|c|c|}
\hline \multicolumn{2}{|r|}{ Model } & $\mathbf{R}$ & $\begin{array}{c}\text { R } \\
\text { Square }\end{array}$ & $\mathrm{F}$ & Sig. & \multicolumn{2}{|c|}{$\begin{array}{c}\text { Unstandardized } \\
\text { Coefficients }\end{array}$} & $\begin{array}{c}\text { Standardized } \\
\text { Coefficients } \\
\text { Beta }\end{array}$ & $\mathrm{t}$ & Sig. & \multicolumn{2}{|c|}{$\begin{array}{l}95.0 \% \text { Confidence } \\
\text { Interval for B }\end{array}$} & \multicolumn{2}{|c|}{$\begin{array}{l}\text { Collinearity } \\
\text { Statistics }\end{array}$} \\
\hline \multirow[t]{7}{*}{1} & (Constant) & \multirow[t]{7}{*}{$.301^{\mathrm{b}}$} & \multirow[t]{7}{*}{.091} & \multirow[t]{7}{*}{4.991} & \multirow[t]{7}{*}{$.000^{\mathrm{b}}$} & 2.166 & 0.362 & & 5.979 & 0.000 & 1.453 & 2.878 & & \\
\hline & Locations & & & & & -0.001 & 0.029 & -0.002 & -0.041 & 0.967 & -0.059 & 0.056 & 0.904 & 1.106 \\
\hline & Age (years) & & & & & 0.040 & 0.051 & 0.042 & 0.780 & 0.436 & -0.061 & 0.140 & 0.899 & 1.112 \\
\hline & Nationality & & & & & -0.035 & 0.157 & -0.012 & -0.225 & 0.822 & -0.344 & 0.273 & 0.969 & 1.032 \\
\hline & Gender & & & & & -0.419 & 0.101 & -0.230 & -4.156 & 0.000 & -0.618 & -0.221 & 0.849 & 1.177 \\
\hline & Educational level & & & & & -0.005 & 0.050 & -0.006 & -0.099 & 0.921 & -0.103 & 0.093 & 0.825 & 1.211 \\
\hline & $\begin{array}{l}\text { Are you from } \\
\text { a health care } \\
\text { professional }\end{array}$ & & & & & 0.352 & 0.098 & 0.194 & 3.600 & 0.000 & 0.160 & 0.544 & 0.891 & 1.122 \\
\hline
\end{tabular}

a. Dependent Variable: the Freqncy of usage the situations hand sanitizer or disinfectant during convid-19a, Predictors: (Constant), Location, Site of work, Age, Nationality, Gender, Educational level, Are you from the health care professional (Medical Doctor- Dentist- Pharmacist- Nurse- Others),

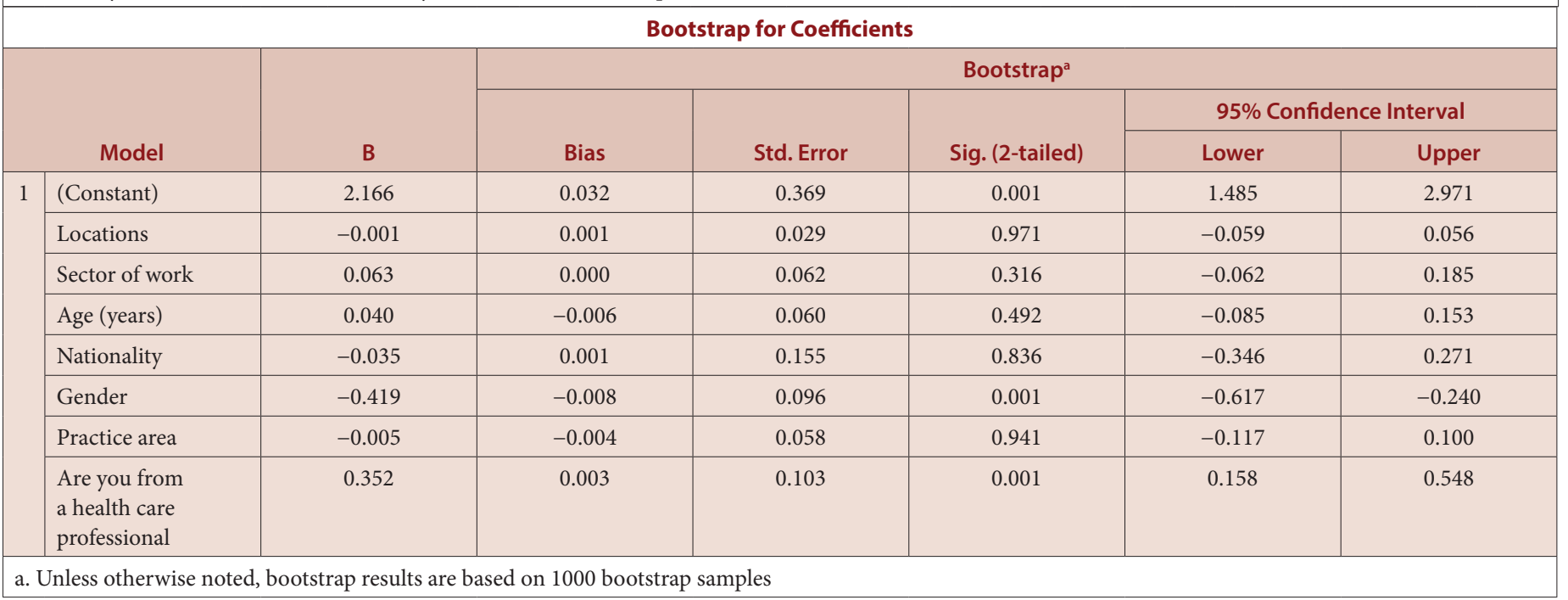

the majority of the factors did not affect the usages. However, other factors affected the frequency of usage, such as the responders from the western region used more than those from the northern region because of a viability of Higher education levels holders and supposed to use sanitizer and disinfectant during COVID-19 to protect them from disease transmission. Moreover, it might reflect high public awareness from healthcare institutions in sanitizer and disinfectants than in the north region. The education of the responder was another factor that could influence the usage of hand sanitizer. Based on this, the responders who completed high school showed high usages for sanitizers and disinfectants, emphasizing brand names because they trusted brand manufacturers more than the generic ones. However, healthcare professionals did not use specific types of brand names of sanitizers and disinfectants. Because all then had location registration in the Ministry of Trade. Older age positively affected the utilization of particular type's sanitizers and disinfectants, emphasizing the brand names. In contrast, educational level was a negative depending factor. The high academic qualification did not use sanitizer and disinfectant brand names, while the low academic qualification holder preferred the brands of sanitizers and disinfectants.
Several factors affected the usage of sanitizers in different situations, and some did. Males used more of it in different situations than females, mainly because males were more in contact with people and worked more during COVID-19. Females were more restricted in the home with the children. The lower age of 18 is many usages than those above 18 because of insufficient knowledge of situations needed for sanitizers and disinfectants. Non-healthcare professionals are more frequently used in various conditions due to inadequate knowledge of sanitizer and disinfectant indications. The gender was dependent on negative situation usage emphasis on male more appropriate indications in the situation and was better than female. Moreover, educational level another depending positive on proper usage in the selection of various conditions due to adequate knowledge of during the practice

\section{Limitations}

This study had many advantages, such as we used an expert validated high-reliability survey with acceptable sample size. However, it had some limitations. First, there was unequal demographic information such as age, occupational status, educational level, occupation. Second, only a few studies are conducted on public knowledge of sanitizer and disinfectants 
to compare current results. Therefore, we recommend further studies with comparable demographic data to cover the drawbacks of the present investigation.

\section{CONCLUSION}

In conclusion, most of the responders used small-sized sanitizers and disinfectants with phenolic and quaternary ammonium salts. The majority of the public used sanitizer or disinfectant after and before market entering situations. Most factors did not affect the use of sanitizer and disinfectants. However, age and members of healthcare professionals are affected more frequently. Therefore, public education about sanitizer and disinfectant utilization is highly recommended to improve appropriate usage and improve the effectiveness of sanitizer and disinfectants. Moreover, we recommend preventing sanitizer and disinfectant-related problems among people in Saudi Arabia. ${ }^{28}$

\section{ACKNOWLEDGEMENT}

None.

\section{CONFLICT OF INTEREST}

The authors declare that there is no conflict of interest.

\section{Funding}

None

\section{Consent for Publications}

Informed consent was obtained from all the participants

\section{Ethical Approval}

This research is exempted from research and ethical committee or an institutional review board (IRB) approval.

https://www.hhs.gov/ohrp/regulations-and-policy/decisioncharts-2018/index.html

\section{ABBREVIATIONS}

COVID-19: Coronavirus; MOH: Ministry of Health; KSA: Kingdom of Saudi Arabia; SPSS: Statistical package of social sciences; JASP: Jeffery's Amazing Statistics Program; STROBE: Strengthening the reporting of observational studies epidemiology.

\section{ORCID ID}

Yousef Ahmed Alomi iD https://orcid.org/0000-0003-1381-628X

\section{REFERENCES}

1. Al-Sayah MH. Chemical disinfectants of COVID-19: An overview. J Water Health. 2020;18(5):843-8. doi: 10.2166/wh.2020.108, PMID 33095205.

2. Rutala WA, Weber DJ. Disinfection, sterilization, and control of hospital waste In: Mandell, Douglas, editors, and Bennett's Principles and Practice of Infectious Diseases; 2014. p. 3294-3309.e1.

3. Rutala WA, Weber DJ, Weinstein RA, Pearson ML. Guideline for disinfection and sterilization in healthcare facilities; 2008. Miscellaneous inactivating agents [internet]. CDC [website. p. 2019]. Available from: http://www.cdc.gov/hicpac/ Disinfection_Sterilization/10_0MiscAgents.html [cited 23/11/2021].

4. Cleaning RE. Coronavirus disease Environmental cleaning and disinfection principles for. 2019;2020(1):1-6.

5. Song X, Vossebein L, Zille A. Efficacy of disinfectant-impregnated wipes used for surface disinfection in hospitals: a review. Antimicrob Resist Infect Control. 2019;8:139. doi: 10.1186/s13756-019-0595-2, PMID 31452873.

6. Rutala WA, Weber DJ. Disinfection and sterilization in health care facilities: What clinicians need to know. Clin Infect Dis. 2004;39(5):702-9. doi: 10.1086/423182. PMID 15356786.
7. Gerster FM, Vernez D, Wild PP, Hopf NB. Hazardous substances infrequently used professional cleaning products. Int J Occup Environ Health. 2014 Jan;20(1):46-60. doi: 10.1179/2049396713Y.0000000052, PMID 24804339.

8. Glegg GA, Richards JP. Chemicals in household products: Problems with solutions. Environ Manage. 2007:40(6):889-901. doi: 10.1007/s00267-007-9022-1, PMID 17902015.

9. Roshan A, Jeevitha M, Sridevi G. Analysis of awareness of infection control in dental practice during the COVID-19 outbreak among dental practitioners in Tamil Nadu. ijrps;11(SPL1):653-8. doi: 10.26452/ijrps.v11iSPL1.3062.

10. Pharmacist_Participation_in_Hand_Hygeine_Compliance_Safdar.

11. Murtough SM, Hiom SJ, Palmer M, Russell AD. A survey of rotational use of biocides in hospital pharmacy aseptic units. J Hosp Infect. 2002;50(3):228-31. doi: 10.1053/jhin.2001.1155, PMID 11886201.

12. Qudeimat MA, Farrah RY, Owais Al. Infection control knowledge and practices among dentists and dental nurses at a Jordanian university teaching center Am J Infect Control. 2006;34(4):218-22. doi: 10.1016/j.ajic.2005.06.012, PMID 16679180.

13. Rauber-Lüthy $\mathrm{C}$, Kupferschmidt $\mathrm{H}$. Household chemicals: Management of intoxication and antidotes. EXS. 2010;100:339-63. doi: 10.1007/978-3-76438338-1_10, PMID 20358689.

14. Sum ZZ, OW CJW. Community pharmacy response to infection control during COVID-19. A cross-sectional survey. Res Social Adm Pharm. 2021;17(1):1845-52. doi: 10.1016/j.sapharm.2020.06.014, PMID 33317763.

15. Adegboye MB, Zakari S, Ahmed BA, Olufemi GH. Knowledge, awareness and practice of infection control by health care workers in the intensive care units of a tertiary hospital in Nigeria. Afr Health Sci. 2018;18(1):72-8. doi: 10.4314/ahs. v18i1.11, PMID 29977260

16. Gharpure R, Miller GF, Hunter CM, Schnall AH, Kunz J, et al. Safe Use and Storage of Cleaners, Disinfectants, and Hand Sanitizers: Knowledge, Attitudes, and Practices among US Adults during the COVID-19 Pandemic, May 2020. Am J Trop Med Hyg. 2020;104(2):496-501. doi: 10.4269/ajtmh.20-1119, PMID 33377450 .

17. Gharpure R, Hunter CM, Schnall AH, Barrett CE, Kirby AE, Kunz J, et al. GarciaWilliams AG Knowledge and Practices Regarding Safe Household Cleaning and Disinfection for COVID-19 Prevention - United States, May 2020. MMWR Morb Mortal Wkly Rep. 2020;69(23):705-9. doi: 10.15585/mmwr.mm6923e2. PMID 32525852.

18. Charan J, Biswas T. How to calculate sample size for different study designs in medical research? Indian J Psychol Med. 2013;35(2):121-6. doi: 10.4103/02537176.116232, PMID 24049221.

19. Pourhoseingholi MA, Vahedi M, Rahimzadeh M. Sample size calculation in medical studies. Gastroenterol Hepatol Bed Bench. 2013;6(1):14-7. PMID 24834239.

20. Ezhumalai DG. How Big A Sample Do I Require?. Annals of SBV. 2017;6(1):39-41. doi: 10.5005/jp-journals-10085-6113.

21. Johnson TP, Wislar JS. Response rates and nonresponse errors in surveys [internet]. JAMA. 2012;307(17):1805-6. doi: 10.1001/jama.2012.3532, PMID 22550194.

22. Von Elm E, Altman DG, Egger M, Pocock SJ, Gøtzsche PC, Vandenbroucke JP. The strengthening the reporting of observational studies in epidemiology (STROBE) statement: Guidelines for reporting observational studies. PLOS Med. 2007;4(10):1623-7. doi: 10.1371/journal.pmed.0040296.

23. Von Elm E, Altman DG, Egger M, Pocock SJ, Gøtzsche PC, Vandenbroucke JP. The Strengthening the Reporting of Observational Studies in Epidemiology (STROBE) statement: guidelines for reporting observational studies [internet] Vol. 370; 2007. Available from: http://www.thelancet.com. Available from: http:// www.plosmedicine.org [cited 23/11/2021]

24. Langan SM, Schmidt SA, Wing K, Ehrenstein V, Nicholls SG, Filion KB, et al. The reporting of studies conducted using observational routinely collected health data statement for pharmacoepidemiology (RECORD-PE). BMJ. 2018;363:k3532. doi: 10.1136/bmj.k3532, PMID 30429167.

25. Liao D, Valliant R. Variance inflation factors in the analysis of complex survey data. Surv Methodol. 2012;38(1):53-62.

26. Akinwande MO, Dikko HG, Samson A. Variance inflation factor: As a condition for the inclusion of suppressor variable(s) in regression analysis. Open J Stat. 2015;05(7):754-67. doi: 10.4236/ojs.2015.57075.

27. Thompson CG, Kim RS, Aloe AM, Becker BJ. Extracting the Variance Inflation Factor and Other Multicollinearity Diagnostics from Typical Regression Results. Basic Appl Soc Psych. 2017;39(2):81-90. doi: 10.1080/01973533.2016.1277529.

28. Octavia DR, Nurafifah D, Utami PR, Pangestu DP. The Effect of Counseling and Training on Public Knowledge about Making Hand sanitizer from Betel Extract. J Asian Multicult Res Med Heal Sci Study. 2021;2(2):8-16. 